Journal of Advanced College of Engineering and Management, Vol. 6, 2021

\title{
IMPACT OF ROAD CUTS IN SLOPE STABILITY IN HILLY REGIONS OF NEPAL
}

\author{
Jagat Kumar Shrestha ${ }^{1}$ \\ ${ }^{1}$ Associate Professor, Department of Civil Engineering, Pulchowk Campus, IoE, T.U.
}

\begin{abstract}
This paper reviews the geological and engineering aspects of rural road construction in the hilly areas of Nepal. The general background in geological, climatic and geographical setting is briefly presented in reference to the five-zone Himalayan model for the Nepal Himalayas. Then, alignment selection of rural roads is discussed in the context of the five zone mountain model. The impact of road cross section design and construction on mountain slopes has been studied. The cut width is a key geometric design parameter that has a significant impact on slope stability and volume of excavation. The choice of cut width in cross-section is reviewed and appropriate cut width in cross-section is recommended in terrain slopes to minimize slope failures and volume of excavation.
\end{abstract}

Keywords: Five zone mountain model, geology, rural roads, slope stability

\section{Introduction}

The geography of Nepal is divided into three bands running the full breadth and comprising the Terai (southern plains), the Mid-Hills and the Mountains. Geography of Nepal comprises one of the most diverse climatic ranges and physical environments in the world. The altitude of the terrain varies from the Gangatic plains in Terai at $70 \mathrm{~m}$ to the Mount Everest at $8848 \mathrm{~m}$ (CBS, 2011), within a distance of $170 \mathrm{~km}$. The Terai (23\% of total area) is only about $30 \mathrm{~km}$ wide. The terrain slope increases rapidly from the end of Terai to the Himalayas. These slopes are the world's steepest slopes, resulting in numerous untameable rivers, tributaries. The hills (52\% of total area) and Himalayas $(25 \%$ of total area) comprise $87 \%$ of the area of the country.

Nepal has a total population of 26.5 million with $83 \%$ living in rural areas. $43 \%$ of the total population of Nepal lives in hills and 7\% in mountains (CBS, 2011). This shows that the hilly regions of Nepal are highly populated. Road constructions in the regions are highly demanded and necessary infrastructure, however, in the difficult terrains.

Road constructions in hilly regions of Nepal have geological and geotechnical issues in the context of slope stability and related geotechnical problems. The overall geological scenario of Nepal is briefly discussed as below.

The Himalayas (Figure 1) is the largest mountain belt of the world, which extends for a total length of about $2400 \mathrm{~km}$. The Nepal Himalayas is situated in the central part of the Himalayan Arc (around 800 $\mathrm{km}$ ), located between the Kumaon Himalaya in the west and the Sikkim-Bhutan Himalaya in the east. The Nepal Himalaya has been divided into the Indo-Gangetic Plain, Sub-Himalaya (Siwalik Group), Lesser Himalaya, Higher Himalaya, and Tibetan-Tethys Himalaya from south to north in sub-tectonic units (Gansser, 1964). The different major geological units are separated by almost east-west running thrust systems that pass through the entire Himalayan region. These thrusts are Indus-Tsangpo Suture, South Tibetan Detachment System (STDS), Main Central Thrust (MCT), Main Boundary Thrust (MBT) and Main Frontal Thrust (MFT), from north to south.

The Indo-Gangetic Plain or Terai forms the southernmost tectonic unit of the Nepal Himalaya, having elevation from 100 to $200 \mathrm{~m}$ from mean sea level and is composed of alluvial deposits. The average thickness of the deposits is about $1.5 \mathrm{~km}$.

The Siwalik Group is delimited by the MBT to the north and the MFT to the south, and lies between 
the Lesser Himalaya and Indo-Gangetic Plain. This unit consists about $6 \mathrm{~km}$ thick Neogene molasses sediments. The sediment comprises mudstone, sandstone and conglomerate.

The Lesser Himalaya lies between the Siwalik Group to the south and the Higher Himalaya to the north. Both the southern and the northern limits of the Lesser Himalaya are represented by the thrust fault; the MBT and the MCT, to the south and north, respectively. It consist thick piles of the sedimentary rocks and low-grade metamorphic rocks. The thickness of the Lesser Himalayan rocks is estimated as more than $14 \mathrm{~km}$.

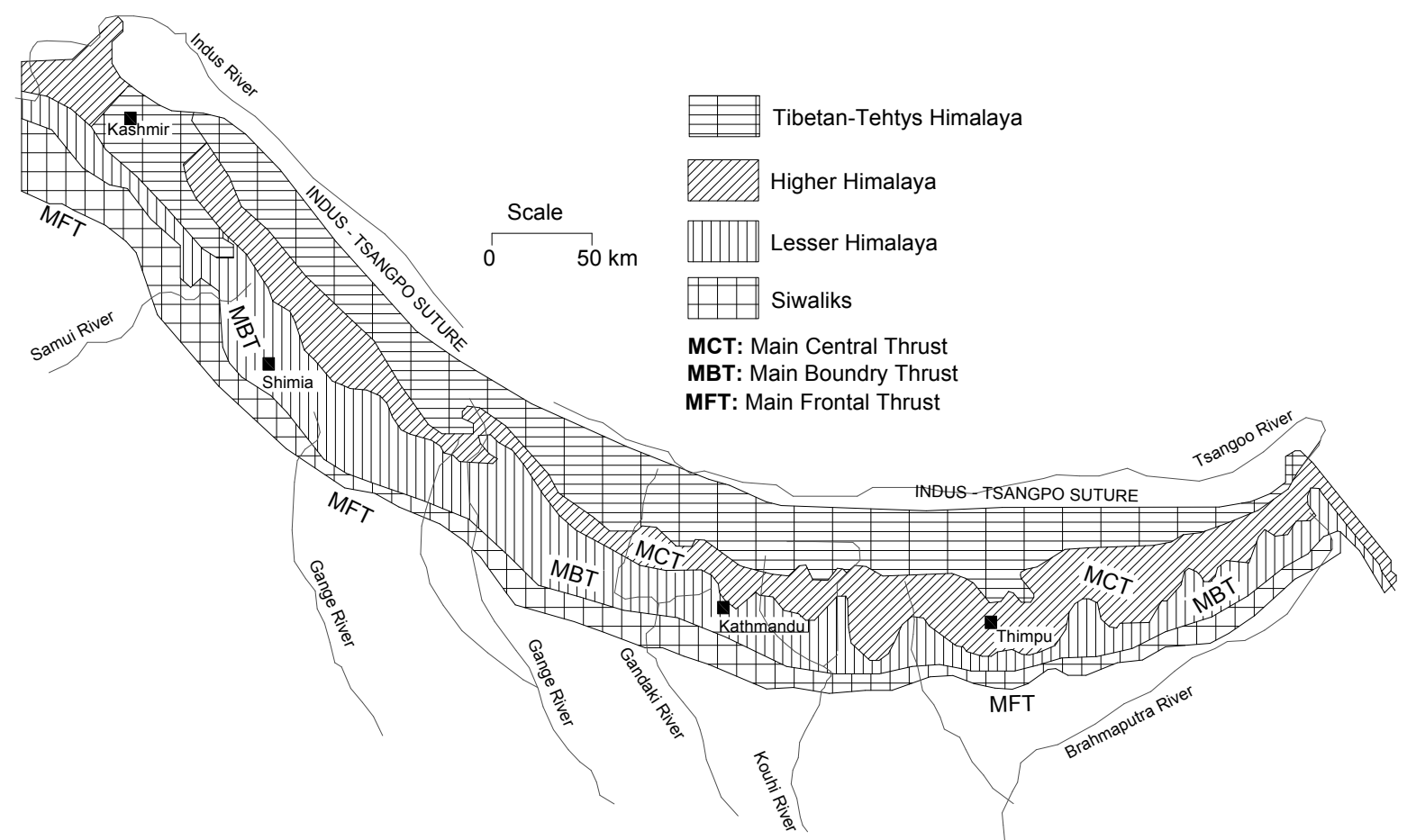

Fig 1: Longitudinal geological subdivision of Himalaya (Gansser, 1964)

The Higher Himalaya is occupied by the high mountains, and lies between the Lesser Himalaya to south and the Tibetan-Tethys Himalaya to the north, which is separated by the MCT in the south and the STDS in the north. The Higher Himalaya is comprised of high-grade metamorphic rocks of schist with granite bodies, pelitic gneisses and migmatites with 6 to $12 \mathrm{~km}$ in thickness.

The Tibetan-Tethys Himalaya is distributed in the northern part of Nepal. The southern border of the Tethys Himalaya is represented by the fault STDS and extends to the north in Tibet. The unit has about $10 \mathrm{~km}$ thick shallow marine sedimentary rock deposits.

Besides geology, the climatic factor, particularly rainfall is important which affect road construction on steep mountain slopes because they have direct links to many aspects of geology, slope stability and drainage. Mountain climates usually vary considerably over short distance because the effects of altitude modify the pattern of regional climate and create broadly vertical zones of climatic type. The decrease in temperature with elevation is approximately linear but the variation of rainfall with elevation is more complex. Generally, rainfall increases with elevation upto certain altitudes usually between 1000 and $2000 \mathrm{~m}$, but then decreases at higher altitudes. However, the effects of local topography and atmospheric conditions are also important. The Mahabharat Range which belongs to the Lesser Himalaya is the most important barrier of the monsoon clouds and it greatly influences the rainfall distribution pattern in Nepal. In the Nepal Himalaya, the most monsoon rain falls on the 
southern windward side of the of the foot hill ranges, increasing with altitude but sharply decreasing in the northern side of each successive range (Nayana, 1975; Dhar and Bhattacharya, 1976).

In addition to technical aspects, socio-economical factors such as settlement distribution and landuse pattern are also important factors in development of road networks in hilly regions of Nepal. Mahabharat Range in the Lesser Himalaya is the most inhabited and cultivated region in Nepal Mountains. The northern part of the Mahabharat range also called midlands has a gentle topography with thick soil formations because of deeply weathered rocks. Basically, in lesser Himalayas, the construction of roads is a major activity and also facing many landslide problems due to disturbance to the mountain slopes.

Further, the geomorphology of mountain slopes has been described in Fookes et. al., (1985) in terms of landforms and erosion processes which are very relevant in the context of road construction in hilly region of Nepal. This is briefly described in section 2. Alignment selection is dealt in section 3. Issues related with design and construction of road cross sections in hilly slope of Nepal is discussed in section 4. Finally, section 5 presents the conclusions.

\section{The five-zone mountain model}

The diversity of topography, geology and climate in mountainous terrain produce a wide range of landforms and related geological and geotechnical problems. This feature has been described in Fookes et. al., (1985) as a simple model of fold mountain topography consisting of five main zones. The model is illustrated in Figure 2 and its units with typical landforms, materials and weathering processes associated with each zone are briefly described as below.

Zone 1: Glacial and peri-glacial topography (typical of the High Himalaya). The rock and ice terrain of the high peaks.

Zone 2: Free rock faces and associated debris slopes (typical of the High Himalaya and highest elevations of the Middle Himalaya). Zone 2 is composed of immature rock fragments and coarse debris covered slopes. Exposed rock peaks, cliffs, ridges, screes, boulder cones and steep slopes mantled with coarse weathering products are the common landforms. Zone 2 scree extends down to the valley bottom. In mountainous areas, most of the rocky outcrops are formed of strong jointed rock and subject to a number of instability processes. The most frequent instability process are rockfalls, wedge, and toppling failures which are usually small.

Zone 3: Degraded middle slopes and ancient valley floors (typical of parts of the Mahabharat Lekh and the of lower elevations of the Middle Himalaya). In comparison with zone 2 and 4, zone 3 topography is distinguished by generally lower average slope angles, a thicker soil cover and relict landforms which reflect the denudation history of the area. The important feature of this zone is that slope stability problems are greatly reduced and constraints on the choice of a road alignment and cross section are less severe than in zone 2 and 4.

Although a wide range of soil and rock materials may be encountered, they are commonly transported (colluvium) soils and in-situ residual soils. Failures caused by excavation occur mainly in the deep residual and colluvial materials on the ancient valley side slopes. The important natural erosion processes on zone 3 slopes are slow soil creep and surface water erosion. This zone is densely populated and cultivated.

Zone 4: Active lower slopes (typical of many parts of the Mahabharat Lekh and some of the more confined slopes adjacent to the major rivers in the Middle Himalaya). The active valley side slopes of zone 4 form a large portion of the landscape. The topography is dominated by steeply sloping valley and gully side slopes covered with a mantle of transported soil overlying weathered bedrock. High 
rates of erosion occur on these slopes and this zone generally creates the most serious problems for road constructions.

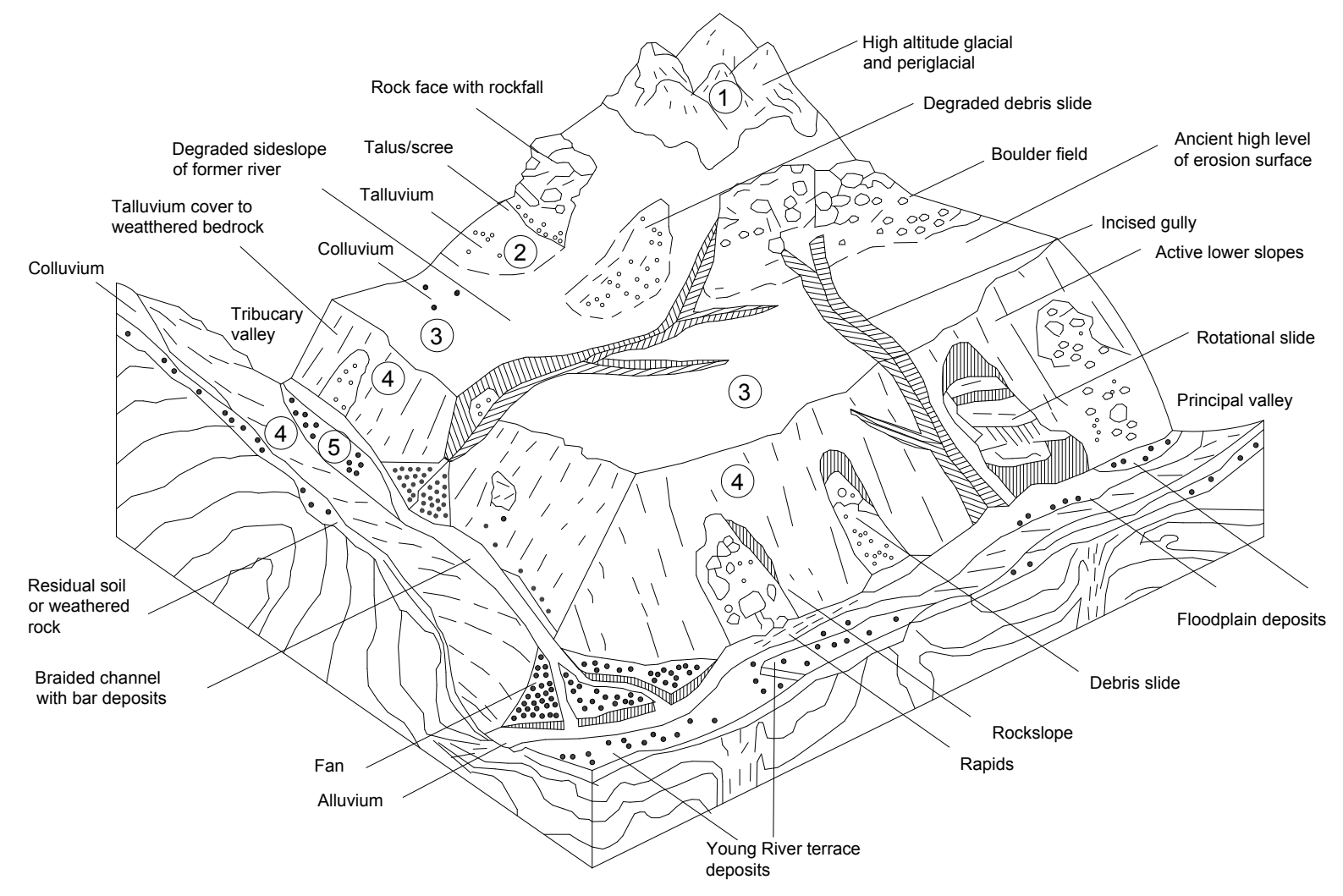

Fig2: Model for young fold mountains (Fookes et. al., 1985)

Less frequently encountered are classical rotational slides and flow failures. Surface water erosion by gullies and rills is the second main process which affects the construction on zone 4 slopes.

The density of the drainage network may be several times higher in zone 4 as compared with zone 3 , an important factor in alignment selection since gully crossings are major cost items.

Zone 5: Valley floors (typical of the Low Himalaya and, to a lesser extent, the Middle Himalaya). The main features of interest are the tributary stream and gully crossings at the point where they flow into the major river valley. Road alignments following the margins of major rivers are a common choice in mountain areas where high velocities and sediment loads during floods would entail difficult and costly construction in mainly zone 5 terrains. These tributary stream outlets are commonly sites of abrupt changes in channel width and bed gradient and favoured locations for sediment deposition. Alluvial fans are the characteristics depositional landforms.

Road constructions (rural roads) are the major activity on mountain terrains particularly more in zone 3 and then in zone 4, less in zone 5 and is largely related with land forms and regional geology along the alignment of roads. The five zone mountain model can be a good basis for alignment selection and cross section designs of roads in hilly region of Nepal.

\section{Alignment selection}

The general principle of locating any road corridor is the shortest length at the minimum gradient and an economy in river crossings and materials. The basic rule of corridor location in reference to the 
mountain model: make distance in zone 3 and make height in zone 4, avoiding extended runs of the lines across zone 4 slopes (Fookes et. al., 1985). The art of the alignment engineer lie in searching out safe zones and linking these by stable corridors and river crossings.

A zone 3 alignment is the most stable and economically desirable. Problems of alignment occur mainly at the zone boundaries. The most important decision is where to enter and leave zone 3 . Instability from below the line is usually more difficult to handle than instability from above. At the higher boundary the alignment is at risk from rock fall. At the lower boundary zone 4, instability may give rise to major scarp face retreat, which is particularly difficult to guard against, and localised gully down-cutting, which needs to be more readily controlled.

Ridgehead route, also known as watershed or spine routes are a special case of zone 3 alignment, fringed entirely by zone 4 , and have been widely adopted.

The objective of alignment within zone 3 will be to minimize cost by a cut and fill balance as much as possible. Cuts and fills will generally be shallow, but where rockhead is also shallow, the vertical alignment can be assessed with care to avoid rock excavation wherever possible.

The aim of the alignment engineer in zone 4 is to search out stable ascent corridors to link zone 5 river crossings with zone 3 slopes. The vertical stacking of hairpin loops is often necessary in zone 4 . A bank of hairpin loops is particularly vulnerable to progressive instability which may develop upslope or down slope from even a minor failure in cut or fill. The cost of retaining structures, drainage, erosion control and stabilisation work is heavy. However, the use of hairpins minimise the overall road length and saving may be set against locally expensive construction at hairpin sites. If the ascent corridor is wide enough, then the hairpins can be split into small groups, offset from the groups immediately above and below to minimise the effects of progressive failures. Furthermore, while setting out a hairpin loops in road alignments, hairpins can be located one above another in such a way that water diverted from the road uphill does not fall on the road segment downhill (Meyer et. al., 1999). This may prevent from progressive failures in the road segments in case of uphill road section failure.

Zone 5 is generally preferred to zone 4 alignments because of the much lower slope angles, although high flood levels in zone 5 may well be decisive factor. These zone 5 routes involve heavy and expensive cross drainage construction but minimise overall length and geotechnical risk. The ideal elevation of the route should be just above the high flood. However, alignment in zone 5 may not preferred for rural roads as the rural roads have generally with unpaved surface and needs a huge numbers of expensive cross drainage structures. Rural roads generally have lowered standard with low cost geometric elements and adequate for low traffic roads.

A full fill cross section will normally be employed in zone 5 in order to avoid cutting into the toe of the zone 4 slopes, except where the encroaching embankment causes more severe problems than those of zone 4.

\section{Design of cross sections}

Design and construction of road cross section can have a big impact on mountain slope. The massive cutting of the mountain slopes and careless disposal of the cut materials downhill, uncontrolled blasting of rock, quarrying and mining activities and improper water management has resulted in intensive soil loss from accelerated erosion, gullying and landslide in Nepal. Every kilometre of road construction may bring about 100000 to 200000 tonnes of excavated materials. Additional 100 tonnes of slide materials can be added per kilometre annually in the case of unprotected cut slopes. The quantity of soil loss is 8000 metric tonnes per hectare per year as a result of careless construction of 
mountain roads. Similarly 1000 metric tonnes per hectare per year of soil loss occurs as a result of lack of maintenance of poorly constructed mountain roads (Deoja, 1994).

Rainfall is usually the most important climatic index. The annual total is not necessarily the most important parameter. In temperate regions, the frequency of slope failure increases substantially when seasonal rainfall is greater than $250 \mathrm{~mm}$ (Radbruch-Hall and Varnes, 1976). This causes a huge occurrence of landslides in mountain slope during monsoon season. It is estimated that 400-700 cubic meters of landslide occurs per km per year along the mountain roads, and 3000 to 9000 cubic meters of landslide occurs per km during the construction of mountain roads in Nepal (Deoja, 1994). The cut slope failure after construction can generate an average of $500 \mathrm{cum} / \mathrm{km} /$ year of debris. Up to 2000 cum $/ \mathrm{km}$ can be generated during single storms with 10-20 years of recurrent intervals (Shrestha, 2010) in Nepal and India.

This has happened due to making excessive cutting that created hill slopes vulnerable to stability at one hand and producing huge volume of excavated materials at the other hand. To reduce these impacts, the quantities of excavation in road cross section need to be reduced. This is possible only when the width and height of cut can be reduced, resulting the less quantity of excavation and minimization of vulnerability of slope failures. Hence, the road cross-section should be such that the cut width and height becomes as lower as possible so that the cut slope is much more stable and safe. The excavated materials need to be used in construction as far as possible and the remaining materials need to be safely dumped so that it will not roll down and cause erosion and landslides.

Nepal Rural Road Standard (NRSS) (DoLIDAR, 1999) has a set of design standard for rural road construction in hilly regions and plain (Terai) regions in rural areas of Nepal as shown in Table 1 . The rural roads have been further classified into district roads and village roads. The village roads have lower geometric standards. It has fixed road formation width as $5 \mathrm{~m}$ for district roads in hilly regions (Table 1). To achieve the formation width, the road cross section can be in fully cut as shown in Figure 3 or partially cut. The partially cut cross sections can be further grouped into two types, the first type with fill and without retaining structures as shown in Figure 4 in mild slopes (slopes less than $30^{\circ}$ ) and the second type with fill and with retaining structures as shown in Figure 5. The partially cut and fill types are the most common road cross sections in hilly regions of Nepal. Retaining structures are unavoidable on hill slopes greater than about $30^{\circ}$, since above this slope angle many common fill materials will of marginal stability, keying in the base of an embankment becomes costly, and overburden soils are prone to shallow sliding. The typical cross section for this type is shown in Figure 5. However, it may be possible to employ well founded and well placed rockfill on slopes up to about $45^{\circ}$. Rock cuts will be unavoidable on slopes greater than $45^{\circ}$ (Fookes et. al., 1985). 
Table 1: Design Standards for rural roads in Nepal (DoLIDAR, 1999)

\begin{tabular}{|c|c|c|c|c|}
\hline \multirow[t]{2}{*}{ Design Parameters } & \multicolumn{2}{|c|}{ District Road } & \multicolumn{2}{|c|}{ Village Road } \\
\hline & Hill & Terai & Hill & Terai \\
\hline Design capacity- in both directions & 200 & 400 & 100 & 200 \\
\hline (Vehicle per day/T.U per day) & $(400)$ & (800) & (200) & $(400)$ \\
\hline Design speed (km per hour) & 20 & 40 & 15 & 30 \\
\hline $\begin{array}{l}\text { Right of way, either side from the } \\
\text { road centre }(\mathrm{m})\end{array}$ & 10 & 10 & 7.5 & 7.5 \\
\hline $\begin{array}{l}\text { Formation width }(\mathrm{m}) \text { - includes } 0.6 \mathrm{~m} \\
\text { drainage } \& 0.4 \mathrm{~m} \text { parapet which will } \\
\text { be kept wherever needed. }\end{array}$ & 5.0 & 6.0 & 4.0 & 4.5 \\
\hline Carriageway width (m) & 3.0 & 3.0 & 3.0 & 3.0 \\
\hline Shoulder width, either side (m) & 1.0 & 1.5 & 0.5 & 0.75 \\
\hline Paving the earthen surface by & $\begin{array}{l}\text { Broken } \\
\text { stones or } \\
\text { Gravel }\end{array}$ & $\begin{array}{l}\text { Gravelling } \\
\text { or Brick } \\
\text { Soling }\end{array}$ & None & None \\
\hline $\begin{array}{l}\text { Minimum radius in horizontal curve } \\
\text { (m) }\end{array}$ & 10 & 20 & 10 & 20 \\
\hline Maximum average gradient (\%) & 8 & 5 & 8 & 5 \\
\hline Maximum gradient (\%) & 12 & 7 & 12 & 7 \\
\hline $\begin{array}{l}\text { Easing of gradient for every } 500 \mathrm{~m} \\
\text { increment in altitude (rate of easing) }\end{array}$ & 0.50 & - & 0.50 & - \\
\hline $\begin{array}{l}\text { Minimum gradient on hill roads (for } \\
\text { better drainage) }(\%)\end{array}$ & 1 & - & 1 & - \\
\hline Free Board from HFL (m) & 0.5 & 0.5 & 0.5 & 0.5 \\
\hline Minimum stopping sight distance (m) & 20 & 40 & 15 & 30 \\
\hline $\begin{array}{l}\text { Cross slope in carriageway camber } \\
(\%)\end{array}$ & 4 & 4 & 5 & 5 \\
\hline Cross slope in shoulder camber (\%) & 5 & 5 & 5 & 5 \\
\hline $\begin{array}{l}\text { Carriageway width at culvert/bridge* } \\
\text { (m) }\end{array}$ & 3.0 & 3.0 & 3.0 & 3.0 \\
\hline $\begin{array}{l}\text { Dimensions (width } \mathrm{x} \text { length) of Lay- } \\
\text { byes/passing zones }(\mathrm{m} \times \mathrm{m})\end{array}$ & $3.0 \times 20$ & $3.0 \times 20$ & $3.0 \times 20$ & $3.0 \times 20$ \\
\hline $\begin{array}{l}\text { Lay-byes/passing zone strips at } \\
\text { interval of }(\mathrm{m})\end{array}$ & 300 & 500 & 300 & 500 \\
\hline
\end{tabular}




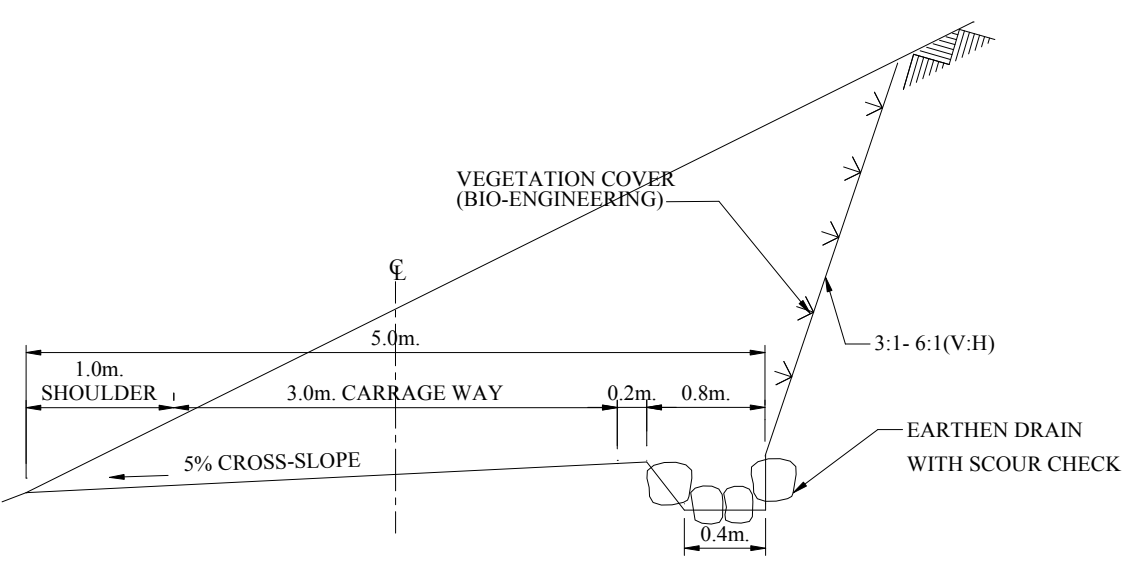

Fig 3: A typical cross-section in full cut.

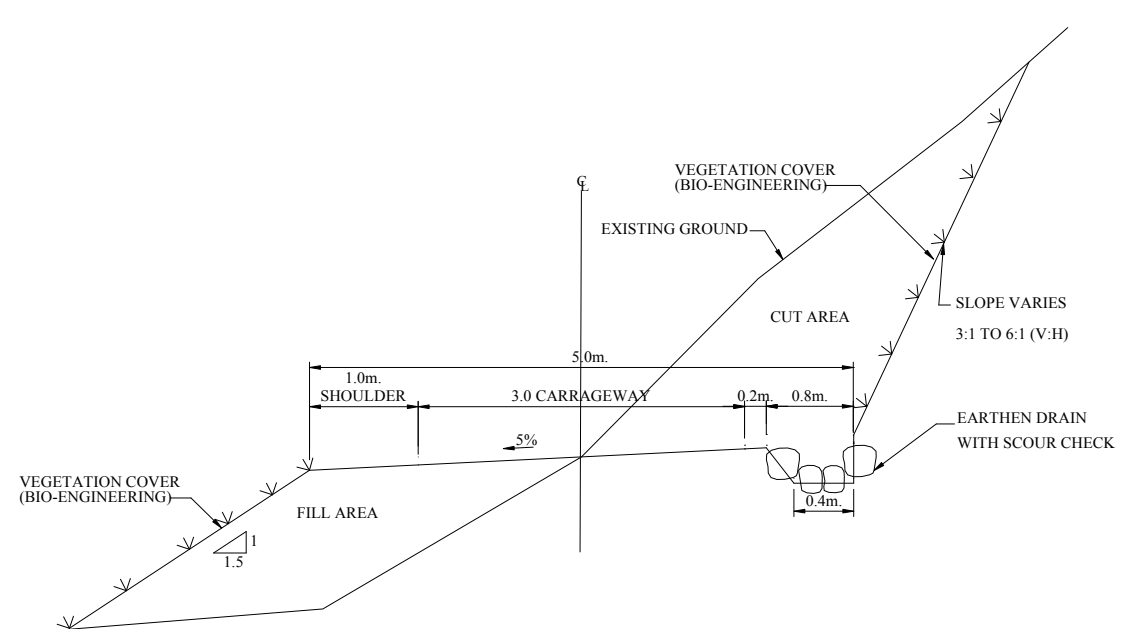

Fig 4: A typical cross-section in mild slopes.

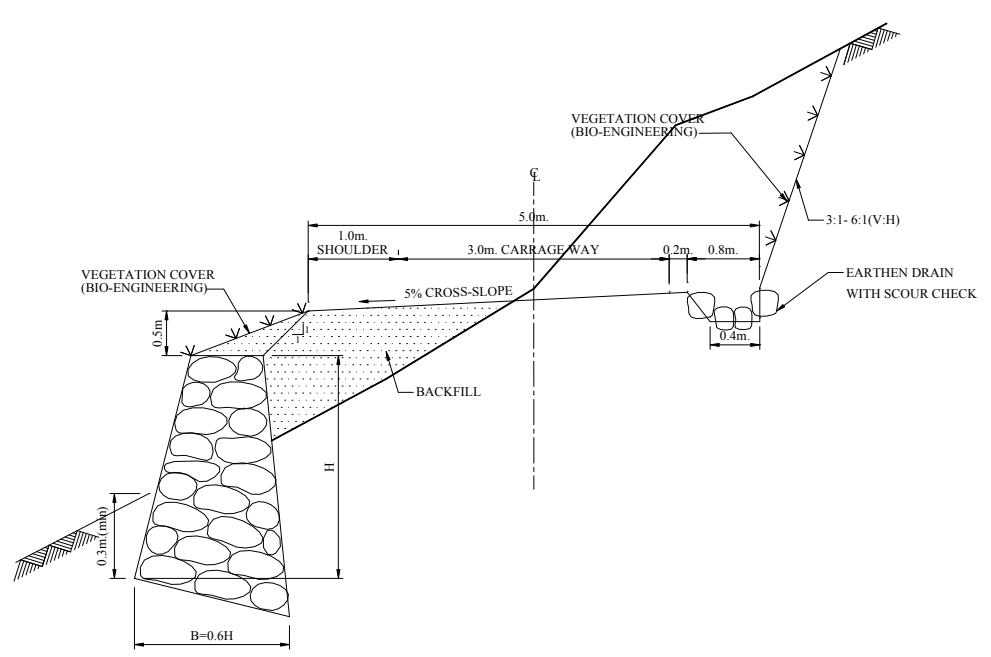

Fig 5: A typical cross-section in cut and fill. 


\subsection{Sensitivity to volume of excavations}

A sensitivity of width of cut to volume of excavation is studied for different slopes and presented in Figure 6. The figure shows that the volume of excavation is very sensitive to width of cut for a mountain slope. For an example, for $30^{\circ}$ slope, the volume of cut in cut width $2 \mathrm{~m}$ is 3.04 cum where as the volume of cut in cut width $5 \mathrm{~m}$ is 12.15 cum which is 4 times greater than the previous. Furthermore, the increase in hill slope is also sensitive to volume of cut. In this case, for an example, for $3 \mathrm{~m}$ cut width, the volume of cut in hill slope $30^{\circ}$ is 5.4 cum where as the volume of cut in $40^{\circ}$ slope is 8.5 cum which is 1.57 times greater than in slope $30^{\circ}$.

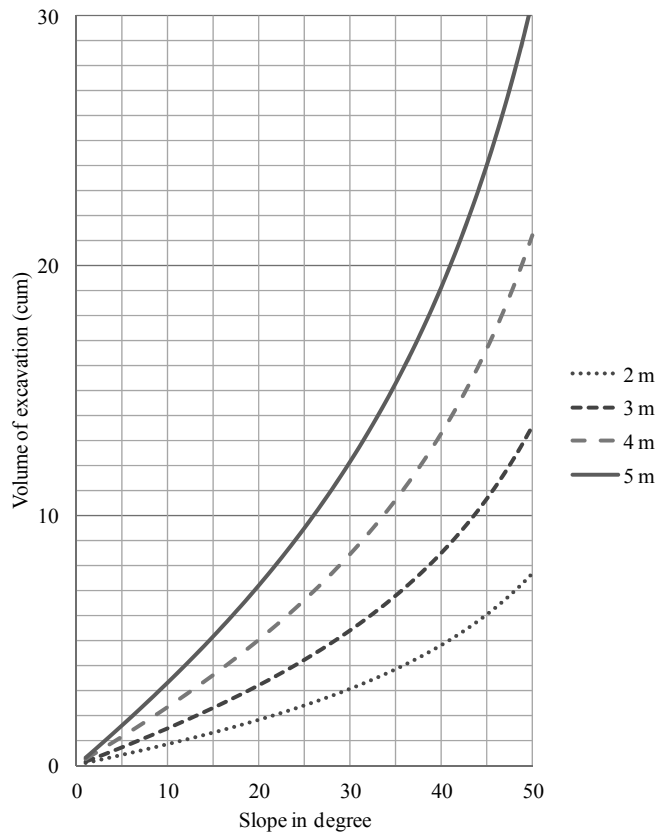

Fig 6: Volume of excavation in hill slopes with cut width $2 \mathrm{~m}, 3 \mathrm{~m}, 4 \mathrm{~m}$, and $5 \mathrm{~m}$.

This study shows that the quantity of cut volume in roads increases significantly with increase in width of cut and the terrain slope in hilly regions. The higher cut width of roads not only generates the higher volume of cut, it also degrades the stability of slopes and gives negative impacts to the local environment. However, control over selection of hill slope may be generally difficult as it is guided by the vertical geometry of roads. The possible way may be minimization of width of cut. Hence, use the cut and fill cross-sections in design and constructions becomes mandatory to achieve the required formation width and to reduce the impacts to quantities of excavation.

\subsection{Impact to slope stability}

A road alignment in hilly regions passes through various slopes. A study shows $28.80 \%$ of road lengths lies in slopes up to $20^{\circ}, 55.33 \%$ of the total road length lies in slopes between $21^{\circ}$ and $40^{\circ}$ and $15.87 \%$ road length lies in slopes above $40^{\circ}$ (Shrestha, 2010).

The situation analysis in different slopes can be made for road cross sections so that the cut width can be controlled to reduce the slope failures. The slope failure problems are related with steepness of hill slopes and soil conditions. Generally, the hilly slopes below $20^{\circ}$ may not be vulnerable to failures. Hence, in this section, the stability of cut slopes has been studied for slopes $20^{\circ}, 30^{\circ}$, and $40^{\circ}$ slopes for cut width $3 \mathrm{~m}, 4 \mathrm{~m}$, and $5 \mathrm{~m}$ for soil slopes. Slopes more than $40^{\circ}$ are usually rock slopes. Analysis of rock slopes are not dealt in this study. 
Morgenstern-Price method (Morgenstern and Price, 1965) is applied to analyse the slopes using slope analysis software, Slope/w, for dry and wet conditions. Then, the results (minimum factor of safety (FoS)) have been presented in Table 2 for dry conditions and in Table 3 for wet conditions for the cut widths and slopes. The soil parameters have been assumed internal friction as $25^{\circ}, 30^{\circ}$ and $35^{\circ}$ and soil cohesion as $5 \mathrm{kPa}, 10 \mathrm{kPa}$, and $15 \mathrm{kPa}$ based on the study (Krahenbuhl and Wagner, 1983) for hilly regions of Nepal.

Table 2: Minimum factor of safety in dry conditions $\left(\gamma=17 \mathrm{kN} / \mathrm{m}^{3}\right)$

\begin{tabular}{|c|c|c|c|c|}
\hline \multirow{2}{*}{$\begin{array}{l}\text { Slope/cut } \\
\text { width }\end{array}$} & \multirow{2}{*}{$\begin{array}{l}\text { Friction } \\
\text { (deg) }\end{array}$} & \multicolumn{3}{|c|}{ FoS for Cohesion $(\mathrm{kPa})$} \\
\hline & & 5 & 10 & 15 \\
\hline \multicolumn{5}{|l|}{ slope20 } \\
\hline \multirow[t]{3}{*}{$3 \mathrm{~m}$ cut } & $\Phi=25$ & 1.944 & 2.586 & 3.111 \\
\hline & $\Phi=30$ & 2.171 & 2.949 & 3.476 \\
\hline & $\Phi=35$ & 2.424 & 3.306 & 3.881 \\
\hline \multirow[t]{3}{*}{$4 \mathrm{~m}$ cut } & $\Phi=25$ & 1.621 & 2.384 & 2.975 \\
\hline & $\Phi=30$ & 1.823 & 2.661 & 3.261 \\
\hline & $\Phi=35$ & 2.046 & 2.947 & 3.578 \\
\hline \multirow[t]{3}{*}{$5 \mathrm{~m}$ cut } & $\Phi=25$ & 1.418 & 1.965 & 2.761 \\
\hline & $\Phi=30$ & 1.534 & 2.174 & 2.956 \\
\hline & $\Phi=35$ & 1.634 & 2.401 & 3.171 \\
\hline \multicolumn{5}{|l|}{ slope30 } \\
\hline \multirow[t]{3}{*}{$3 \mathrm{~m}$ cut } & $\Phi=25$ & 1.297 & 1.728 & 2.098 \\
\hline & $\Phi=30$ & 1.503 & 1.934 & 2.341 \\
\hline & $\Phi=35$ & 1.717 & 2.162 & 2.594 \\
\hline \multirow[t]{3}{*}{$4 \mathrm{~m}$ cut } & $\Phi=25$ & 1.197 & 1.524 & 1.861 \\
\hline & $\Phi=30$ & 1.405 & 1.731 & 2.057 \\
\hline & $\Phi=35$ & 1.614 & 1.959 & 2.288 \\
\hline \multirow[t]{3}{*}{$5 \mathrm{~m}$ cut } & $\Phi=25$ & 0.924 & 1.234 & 1.526 \\
\hline & $\Phi=30$ & 1.068 & 1.399 & 1.714 \\
\hline & $\Phi=35$ & 1.228 & 1.573 & 1.852 \\
\hline \multicolumn{5}{|l|}{ slope40 } \\
\hline \multirow[t]{3}{*}{$3 \mathrm{~m}$ cut } & $\Phi=25$ & 0.834 & 1.080 & 1.251 \\
\hline & $\Phi=30$ & 0.902 & 1.224 & 1.459 \\
\hline & $\Phi=35$ & 1.028 & 1.383 & 1.620 \\
\hline \multirow[t]{3}{*}{$4 \mathrm{~m}$ cut } & $\Phi=25$ & 0.733 & 0.953 & 1.112 \\
\hline & $\Phi=30$ & 0.854 & 1.089 & 1.263 \\
\hline & $\Phi=35$ & 0.949 & 1.210 & 1.430 \\
\hline \multirow[t]{3}{*}{$5 \mathrm{~m}$ cut } & $\Phi=25$ & 0.663 & 0.879 & 1.041 \\
\hline & $\Phi=30$ & 0.795 & 1.010 & 1.173 \\
\hline & $\Phi=35$ & 0.935 & 1.113 & 1.313 \\
\hline Note: & & "Vulnerable & ections & \\
\hline
\end{tabular}


Table 2 shows the distribution of factor of safety across the different hill slopes at cut width $3 \mathrm{~m}, 4 \mathrm{~m}$, and $5 \mathrm{~m}$ on parameters internal friction angle and cohesion of soil. Viewing to the results in Table 2 for dry conditions, the minimum factor of safety is adequate (greater than unity) for:

- $20^{\circ}$ slope with cut width all $(3 \mathrm{~m}, 4 \mathrm{~m}$, and $5 \mathrm{~m})$ except $30^{\circ}$ slope with cut width $5 \mathrm{~m}$ for $\Phi=25$ (for $\mathrm{c}>=5 \mathrm{kPa}$ ) and

- $30^{\circ}$ slope with cut width $5 \mathrm{~m}$ and $40^{\circ}$ slope with cut width all (for $\mathrm{c}>=10 \mathrm{kPa}$ ) except for $\Phi=25$.

The $40^{\circ}$ slope is vulnerable to all cut widths for weak soils (for $\mathrm{c}<=5 \mathrm{kPa}$ ). These results show that the cut slopes can be vulnerable to failure even in dry conditions. However, this table is less relevant as the slopes are more vulnerable in wet conditions.

Table 3: Minimum factor of safety in dry conditions $\left(\gamma=21 \mathrm{kN} / \mathrm{m}^{3}\right)$

\begin{tabular}{|c|c|c|c|c|}
\hline \multirow{2}{*}{$\begin{array}{l}\text { Slope/cut } \\
\text { width }\end{array}$} & \multirow{2}{*}{$\begin{array}{l}\text { Friction } \\
\text { (deg) }\end{array}$} & \multicolumn{3}{|c|}{ FoS for Cohesion $(\mathrm{kPa})$} \\
\hline & & 5 & 10 & 15 \\
\hline \multicolumn{5}{|l|}{ slope20 } \\
\hline \multirow[t]{3}{*}{$3 \mathrm{~m}$ cut } & $\Phi=25$ & 1.756 & 2.384 & 2.811 \\
\hline & $\Phi=30$ & 1.934 & 2.707 & 3.177 \\
\hline & $\Phi=35$ & 2.236 & 3.036 & 3.578 \\
\hline \multirow[t]{3}{*}{$4 \mathrm{~m}$ cut } & $\Phi=25$ & 1.474 & 2.151 & 2.637 \\
\hline & $\Phi=30$ & 1.675 & 2.410 & 2.924 \\
\hline & $\Phi=35$ & 1.898 & 2.696 & 3.229 \\
\hline \multirow[t]{3}{*}{$5 \mathrm{~m}$ cut } & $\Phi=25$ & 1.240 & 1.756 & 2.391 \\
\hline & $\Phi=30$ & 1.338 & 1.964 & 2.407 \\
\hline & $\Phi=35$ & 1.517 & 2.193 & 2.636 \\
\hline \multicolumn{5}{|l|}{ slope30 } \\
\hline \multirow[t]{3}{*}{$3 \mathrm{~m}$ cut } & $\Phi=25$ & 1.215 & 1.564 & 1.893 \\
\hline & $\Phi=30$ & 1.408 & 1.769 & 2.119 \\
\hline & $\Phi=35$ & 1.618 & 1.997 & 2.347 \\
\hline \multirow[t]{3}{*}{$4 \mathrm{~m}$ cut } & $\Phi=25$ & 0.938 & 1.261 & 1.528 \\
\hline & $\Phi=30$ & 1.087 & 1.426 & 1.724 \\
\hline & $\Phi=35$ & 1.152 & 1.564 & 1.892 \\
\hline \multirow[t]{3}{*}{$5 \mathrm{~m}$ cut } & $\Phi=25$ & 0.863 & 1.131 & 1.386 \\
\hline & $\Phi=30$ & 0.894 & 1.263 & 1.515 \\
\hline & $\Phi=35$ & 1.029 & 1.424 & 1.698 \\
\hline \multicolumn{5}{|l|}{ slope40 } \\
\hline \multirow[t]{3}{*}{$3 \mathrm{~m}$ cut } & $\Phi=25$ & 0.786 & 0.969 & 1.096 \\
\hline & $\Phi=30$ & 0.916 & 1.125 & 1.266 \\
\hline & $\Phi=35$ & 0.980 & 1.279 & 1.454 \\
\hline \multirow[t]{3}{*}{$4 \mathrm{~m}$ cut } & $\Phi=25$ & 0.691 & 0.881 & 1.021 \\
\hline & $\Phi=30$ & 0.778 & 0.991 & 1.171 \\
\hline & $\Phi=35$ & 0.955 & 1.126 & 1.321 \\
\hline \multirow[t]{3}{*}{$5 \mathrm{~m}$ cut } & $\Phi=25$ & 0.620 & 0.793 & 0.943 \\
\hline & $\Phi=30$ & 0.775 & 0.912 & 1.075 \\
\hline & $\Phi=35$ & 0.904 & 1.084 & 1.190 \\
\hline Note: & & \multicolumn{2}{|c|}{ Vulnerable sections } & \\
\hline
\end{tabular}


Based on the results of slope analysis in wet condition (Table 3), the factor of safety has been found adequate for:

- $20^{\circ}$ slope with cut width all $(3 \mathrm{~m}, 4 \mathrm{~m}$, and $5 \mathrm{~m})$ and $30^{\circ}$ slope with cut widths $3 \mathrm{~m}$ and $4 \mathrm{~m}$ (for $\mathrm{c}>=5 \mathrm{kPa}$ ) except for $\Phi=25$,

- $30^{\circ}$ slope with cut width $4 \mathrm{~m}$ and $5 \mathrm{~m}$ and $40^{\circ}$ slope with cut width $3 \mathrm{~m}$ (for $\mathrm{c}>=10 \mathrm{kPa}$ ), and

- $40^{\circ}$ slope with cut width $4 \mathrm{~m}$ and $5 \mathrm{~m}$ (for $\mathrm{c}>=15 \mathrm{kPa}$ ) except for $\Phi=25$.

For this condition, the $40^{\circ}$ slope is more vulnerable to all cut widths. In real world also, all most all the slope failure occurs during monsoon season in Nepal. Hence, wet condition factor of safeties prevails. Then, from the results of wet conditions, the following recommendation for cut widths can be made in slope soil matrix as shown in Table 4.

Table 4: Recommended cut width in (m)

\begin{tabular}{|l|l|l|l|}
\hline \multirow{2}{*}{$\begin{array}{l}\text { Hill } \\
\text { Slope }\left(^{\circ}\right)\end{array}$} & \multicolumn{3}{|l|}{ Cohesion $(\mathrm{kPa})$} \\
\cline { 2 - 4 } & 5 & 10 & 15 \\
\hline 20 & 5 & 5 & 5 \\
\hline 30 & 3 & 5 & 5 \\
\hline 40 & - & 3 & 4 \\
\hline
\end{tabular}

Table 4 shows that full cut section can only be made for hill slopes up to $20^{\circ}$. For $30^{\circ}$ slope, full cut section $(5 \mathrm{~m})$ can be made for soils which have cohesion value greater the $10 \mathrm{kPa}$. The cut widths to be limited to $3 \mathrm{~m}$ for soils with cohesion equal or more than $5 \mathrm{kPa}$ but less than $10 \mathrm{kPa}$.

For slopes $40^{\circ}$ and more than $40^{\circ}$, full cut sections may not be recommended. Even $3 \mathrm{~m}$ cut is not recommended for weak soils ( $c=5 \mathrm{kPa}$ ). The cut widths is recommended to be limited to $3 \mathrm{~m}$ for soils with cohesion more than $10 \mathrm{kPa}$ but less than $15 \mathrm{kPa}$ and $4 \mathrm{~m}$ cut for soil with cohesion $15 \mathrm{kPa}$ for $40^{\circ}$ slope.

\section{Conclusions}

In this paper, we made a review of geological and geomorphological conditions for road constructions in hilly regions of Nepal. The five zone mountain model can be a rational framework for fixing road alignments. Mostly, rural roads in hilly regions of Nepal pass through mountain zone 3 and zone 4 as zone 3 is densely populated and cultivated and it is the most stable areas for settlements and cultivations.

Design and construction of road cross section have negative impacts to hill slopes due to reduction in factor of safety after cutting and resulting vulnerable to landslides. The excessive excavated materials also cause slope stability problems. The cut width is the key geometrical parameter and very sensitive to slope stability and volume of excavated materials.

The study has recommended different cut widths for hill slopes $20^{\circ}-40^{\circ}$ which can be a general basis for cross section design for rural roads in hilly regions so that slope failure problems can be minimized. For higher slopes and weak soil slopes, width of cut in sections to be limited, hence, cut and fill cross-section with valley side retaining structures may be mandatory to achieve the road formation width. 


\section{References}

1. Central Bureau of Statistics (CBS), (2011). "Nepal in Figures". National Planning Commission secretariat, Government of Nepal.

2. Deoja, B. B. (1994). "Sustainable Approaches to the Construction of Roads and Other Infrastructure in the Hindu Kush-Himalayas", ICIMOD, Occasional Paper No. 24

3. Dhar, O.N., and Bhattacharya, B.K. (1976). "Variation of rainfall with elevation in the Himalayas - a pilot study”. Indian J. Power River Val. Dev. 26(6):179-185.

4. DoLIDAR (1999). "Approach for the Development of Agricultural and Rural Roads: A Manual for the Preparation of District Transport Master Plan and for the Implementation of Rural Road Sub-projects". ILO/ Ministry of Local Development, Government of Nepal, Kathmandu.

5. Fookes, P.G.,M. Sweeney, Manby, C.N.D. and Martin, R.P.(1985). "Geological and geotechnical engineering aspects of low-cost roads in mountainous terrain". Engineering Geology, 21:1-152.

6. Gansser, A. (1964). "Geology of the Himalayas". Interscience, Wiley, New York, 1-289.

7. Krahenbuhl, J., and Wagner, A. (1983). "Survey, design and construction of trail suspension bridges for remote areas, Volume B". Swiss Centre for Appropriate Technology, Switzerland. $1-325$,

8. Meyer, W.,Acharya, B.N. Aryal and Karmacharya, R. B. (1999). "Green Roads in Nepal Best Practice Report”, SCD/GTZ. 1-95

9. Morgenstern, N.R. and Price, V.E. (1965). "The Analysis of the Stability of General Slip Surfaces". Geotechnique, 15:79-93.

10. Nayana, J.L. (1974). “Heavy monsoon rainfall in Nepal”. Weather, 29(12): 443-450.

11. Radbruch-Hall, D.H. and Varnes, D.T. (1976). "Landslides - Cause and effects". Bull. Int. Assoc. Eng. Geol., 14:205-216

12. Shrestha, H. R. (2010). "Road vs. Hill Environment: The Trend of Road Construction in Nepal Transport in Mountains". Transport in Mountains, An International Workshop, 21-27 November, Kathmandu, Nepal. 